\title{
Efektivitas Model Pembelajaran Kooperatif Tipe Teams Games Tournaments (TGT) untuk Meningkatkan Aktivitas dan Prestasi Belajar Siswa
}

\author{
Muhammad Juaini ${ }^{*}$ \\ ${ }^{1}$ SMAN 3 Selong Lombok Timur NTB \\ *email: muhammadjuaini72@gmail.com
}

\begin{abstract}
One of the problems of education in Indonesia is the low quality at every level and unit of education, mainly primary and secondary education. Based on observations made by researchers at SMAN 3 Selong, it was shown that the learning outcomes of Grade X MIPA-3 students obtained the lowest classical completeness, which was $37.5 \%$, so that they had not yet achieved the classical completeness set, namely students who achieved $\mathrm{KKM} \geq 85 \%$. This is because teachers still use the conventional approach that is dominated by the lecture method. To overcome this, we need a learning approach that can improve student learning outcomes by connecting students' initial knowledge with the material being studied, where students are more active in the teaching and learning process. One approach that can overcome the above is the Teams Games Tournaments (TGT) cooperative learning model approach. This study aims to determine the application of the TGT type learning model in improving student learning activities and achievement on the trigonometric subject matter in class X MIPA-3 SMAN 3 Selong academic year 2019/2020 with 36 students. This type of research is Classroom Action Research consisting of planning, implementation, observation, evaluation, and reflection. The results of the study show that students are more active in the teaching and learning process, and there is an increase in mathematics learning achievement in class X MIPA-3 SMAN 3 Selong by applying a cooperative model type of TGT on trigonometric subject matter learning. This improvement in achievement can be seen from the increase in the percentage of students completeness in classical learning in the first cycle with classical completeness of $65.71 \%$, the second cycle with classical completeness of $76.47 \%$, and in the third cycle with classical completeness of $90.09 \%$. Besides that, after implementing the TGT type cooperative model, student learning activities increase each cycle with active, active, and very active criteria. From the results of this study, it can be concluded that the application of the TGT type cooperative model in trigonometric subject matter learning can improve student learning activities and achievement Class $\mathrm{X}$ MIPA-3 SMAN 3 Selong in the academic year 2019/2020.
\end{abstract}

Keywords: TGT Learning Model; Activity; Learning achievement

\begin{abstract}
Abstrak
Salah satu permasalahan pendidikan di Indonesia adalah rendahnya mutu pada setiap jenjang dan satuan pendidikan, khususnya pendidikan dasar dan menengah. Berdasarkan hasil pengamatan yang dilakukan peneliti di SMAN 3 Selong menunjukkan bahwa hasil belajar siswa kelas X MIPA-3 memperoleh ketuntasan klasikal yang paling rendah yaitu sebesar 37,5\% sehingga belum mencapai ketuntasan klasikal yang ditetapkan yaitu siswa yang mencapai $\mathrm{KKM} \geq 85 \%$. Hal ini disebabkan karena guru masih menggunakan pendekatan konvensional yang di dominasi metode ceramah. Untuk mengatasinya, diperlukan suatu pendekatan pembelajaran yang mampu meningkatkan hasil belajar siswa dengan menghubungkan pengetahuan awal siswa dengan materi yang sedang dipelajari, dimana siswa lebih aktif dalam proses belajar mengajar. Salah satu pendekatan yang dapat mengatasi hal tersebut di atas adalah pendekatan model pembelajaran kooperatif tipe Teams Games Tournaments (TGT).Penelitian ini bertujuan untuk mengetahui penerapan model pembelajaran tipe TGT dalam meningkatkan aktivitas dan prestasi belajar siswa pada materi pokok trigonometri di kelas X MIPA-3 SMAN 3 Selong tahun pelajaran 2019/2020 dengan jumlah siswa 36 orang. Jenis penelitian ini adalah Penelitian Tindakan Kelas yang terdiri dari perencanaan, pelaksanaan, observasi, evaluasi dan refleksi.Hasil penelitian menunjukkan bahwa siswa lebih aktif dalam proses belajar mengajar dan terjadi peningkatan prestasi belajar matematika siswa kelas X MIPA-3 SMAN
\end{abstract}


3 Selong dengan menerapkan model kooperatif tipe TGT pada pembelajaran materi pokok trigonometri. Peningkatan prestasi ini dilihat dari meningkatnya presentase ketuntasan belajar siswa secara klasikal pada siklus I dengan ketuntasan klasikal sebesar 65,71\%, siklus II dengan ketuntasan klasikal sebesar 76,47\% dan pada siklus III dengan ketuntasan klasikal sebesar 90,09\%. Selain itu setelah mengimplementasikan dengan model kooperatif tipe TGT, aktivitas belajar siswa meningkat tiap siklusnya dengan kriteria aktif, aktif, dan sangat aktif.Dari hasil penelitian ini dapat disimpulkan bahwa penerapan model kooperatif tipe TGT pada pembelajaran materi pokok trigonometri dapat meningkatkan aktivitas dan prestasi belajar siswa kelas X MIPA-3 SMAN 3 Selong tahun pelajaran 2019 / 2020.

Kata Kunci: Model Pembelajaran TGT; Aktivitas; Prestasi Belajar

\section{PENDAHULUAN}

Salah satu permasalahan pendidikan di Indonesia adalah rendahnya mutu pada jenjang dan satuan pendidikan, khususnya pendidikan dasar dan menengah. Berbagai usaha telah dilakukan untuk meningkatkan mutu pendidikan nasional, antara lain melalui berbagai pelatihan dan peningkatan kualifikasi guru, penyempurnaan kurikulum, pengadaan buku dan alat pengajaran, perbaikan sarana dan prasarana pendidikan lainnya, peningkatan mutu manajemen sekolah. Tujuan pembelajaran adalah terwujudnya efisiensi dan efektivitas kegiatan belajar yang dilakukan peserta didik.

Model pembelajaran merupakan strategi yang digunakan untuk meningkatkan motivasi belajar, sikap belajar di kalangan siswa, mampu berpikir kritis, memiliki keterampilan sosial, dan pencapaian hasil belajar yang maksimal. Karena itulah, perkembangan model pembelajaran dari waktu ke waktu terus mengalami perubahan. Kesalahan dalam pemilihan model pembelajaran tersebut terjadi pula dalam pembelajaran matematika. Matematika adalah salah satu pelajaran mendasar yang diajarkan di sekolah karena matematika merupakan ilmu yang menjadi dasar bagi bidang studi lain seperti Ilmu Pengetahuan Alam hingga Ilmu Pengetahuan Sosial. Sebagai ilmu eksakta, untuk mempelajarinya tidak cukup hanya dengan hapalan dan membaca, tetapi memerlukan pemikiran dan pemahaman. Maka dari itu pengajar harus dapat menggunakan model pembelajaran dan pendekatan mengajar yang dapat menjamin pembelajaran berhasil sesuai dengan yang direncanakan. Berdasarkan observasi yang dilakukan peneliti di kelas X SMAN 3 Selong didapatkan data ketuntasan belajar siswa sebagai berikut:

Tabel 1. Data ketuntasan belajar siswa kelas X SMAN 3 Selong pada Semester Genap Tahun Pelajaran 2019/2020

\begin{tabular}{cccc}
\hline No & Kelas & Jumlah siswa & Ketuntasan yang dicapai \\
\hline 1 & X MIPA-1 & 36 & $41.67 \%$ \\
2 & X MIPA-2 & 36 & $75,00 \%$ \\
3 & X MIPA-3 & 32 & $37.50 \%$ \\
4 & X IPS-1 & 34 & $73.52 \%$ \\
5 & X IPS-2 & 33 & $63.64 \%$ \\
6 & X IPS-3 & 33 & $70,01 \%$ \\
7 & X IPS-4 & 32 & $40,38 \%$ \\
\hline
\end{tabular}




\section{Mandalika Mathematics and Education Journal \\ Volume 2 Nomor 1, Juni 2020 e-ISSN 2715-1190 | | p-ISSN 2715-8292 \\ DOI: http://dx.doi.org/10.29303/mandalika.v2i1.1893}

Tabel 1 menunjukkan bahwa ketuntasan belajar kelas $X$ SMAN 3 Selong belum mencapai standar ketuntasan belajar/klasikal yang ditetapkan oleh Dinas Pendidikan Nasional sebesar 85\%. Dan kelas X MIPA-3 mendapatkan ketuntasan belajar paling rendah yaitu 37,5\%. Hal ini menunjukkan bahwa daya serap siswa kelas X MIPA 3 yang mencapai Kriteria Ketuntasan Minimum (KKM) yang ditetapkan sekolah sebesar 67 kurang dari setengah jumlah siswa. Berdasarkan informasi dari guru matematika yang lain kelas $X$ SMAN 3 Selong tahun pelajaran 2019/2020 bahwa hasil belajar siswa kelas $X$ belum mencapai ketuntasan yang ditetapkan. Nilai rata-rata yang diperoleh siswa kelas pada beberapa materi pokok yang diajarkan dalam semester genap dipaparkan dalam bentuk tabel berikut.

Tabel 2 Hasil ulangan harian siswa kelas $X$ di SMAN 3 Selong Tahun Pelajaran 2019/2020

\begin{tabular}{|c|c|c|c|c|c|c|c|}
\hline \multirow[b]{2}{*}{ No } & \multirow[b]{2}{*}{ Kelas } & \multicolumn{3}{|c|}{ Nilai rata-rata materi pokok } & \multicolumn{3}{|c|}{ Ketuntasan klasikal materi ke- } \\
\hline & & $\begin{array}{l}\text { Pers dan } \\
\text { Prtd Nilai } \\
\text { Mutlak (1) }\end{array}$ & $\begin{array}{l}\text { Trigonome } \\
\text { tri (2) }\end{array}$ & $\begin{array}{c}\text { Pers } \\
\text { Rasional } \\
\text { dan } \\
\text { Irasional } \\
\text { Satu Var } \\
\text { (3) }\end{array}$ & (1) & $(2)$ & (3) \\
\hline 1 & X MIPA-1 & 66.68 & 65.79 & 68.68 & $47.4 \%$ & $42.1 \%$ & $55.3 \%$ \\
\hline 2 & X MIPA-2 & 67.18 & 58.87 & 69.47 & $65.8 \%$ & $39.5 \%$ & $65.8 \%$ \\
\hline 3 & X MIPA-3 & 68.42 & 63.21 & 68.47 & $73.7 \%$ & $63.2 \%$ & $68.4 \%$ \\
\hline 4 & X IPS-1 & 67.95 & 65.50 & 67.32 & $71.1 \%$ & $65.8 \%$ & $63.2 \%$ \\
\hline 5 & X IPS-2 & 71.08 & 62.23 & 69.77 & $86.8 \%$ & $48.8 \%$ & $63.2 \%$ \\
\hline 6 & X IPS-3 & 66,67 & 65,50 & 67,30 & $71,2 \%$ & $45,3 \%$ & $63,6 \%$ \\
\hline 7 & X IPS-4 & 67,02 & 60,76 & 69,70 & $65,4 \%$ & $46,1 \%$ & $64,5 \%$ \\
\hline
\end{tabular}

Tabel 2 menunjukkan bahwa nilai rata-rata dari materi pokok trigonometri paling rendah diantara materi pokok yang lain dan belum mencapai KKM yang ditetapkan. Hal ini disebabkan karena dalam pembelajaran matematika tidak semua pokok bahasan dapat menggunakan suatu model pembelajaran yang sama, maka dari itu seorang guru harus dapat memilih suatu model pembelajaran yang sesuai. Khusus materi pokok trigonometri, terdapat banyak penerapan rumus sehingga diperlukan latihan soal yang lebih. Di samping itu terkadang siswa mengalami kesulitan dalam menggunakan rumus dan tidak berani bertanya kepada gurunya.

Oleh karena itu sebagai alternatif pilihan dalam mengajar pokok bahasan trigonometri dapat digunakan model pembelajaran kooperatif. Sebagaimana yang diungkapkan Arizona, dkk (2013) bahwa pembelajaran kooperatif membantu siswa memahami konsepkonsep yang sulit dan menumbuhkan kemampuan siswa dalam bekerjasama. Strategi pembelajaran kooperatif memiliki pengaruh positif terhadap hasil belajar. Senada apa yang dinyatakan oleh Harjono, dkk (2015) pembelajaran kooperatif merupakan bentuk pembelajaran dengan cara siswa belajar dan bekerja dalam kelompok-kelompok kecil 


\section{Mandalika Mathematics and Education Journal \\ Volume 2 Nomor 1, Juni 2020 e-ISSN 2715-1190 | | p-ISSN 2715-8292 \\ DOI: http://dx.doi.org/10.29303/mandalika.v2i1.1893}

secara kolaboratif dengan struktur kelompok bersifat heterogen. Pembelajaran kooperatif sangat dianjurkan oleh para ahli pendidikan. Salah satu tipe pembelajaran kooperatif yang dapat diterapkan adalah tipe Teams Games Tournaments (TGT). TGT merupakan salah satu strategi pembelajaran kooperatif yang dikembangkan oleh Slavin (1995) untuk membantu siswa mereview dan menguasai materi pelajaran (Huda, 2013). Langkah-langkah model pembelajaran kooperatif tipe Teams Games Tournament menurut Sani (2014) yaitu: (1) guru memilih topik pembelajaran dan menyajikannya pada siswa; (2) guru mengembangkan daftar pertanyaan, memberi nomor, dan mengguntingnya menjadi potongan kecil; (3) guru mengelompokkan siswa secara heterogen bergantung pada kemampuannya dalam beberapa kelompok. Siswa diminta mengambil nomor dari sebuah kotak dan harus menjawab pertanyaan yang sesuai dengan nomor yang diambil; (4) guru menempatkan siswa dalam beberapa kelompok pertandingan, di mana anggota kelompok yang baru tersebut memiliki kompetensi yang sama (homogen). Masing-masing kelompok menghadapi "meja pertandingan". Turnamen dilakukan dengan menjawab pertanyaan yang diberikan. Siswa memperoleh nilai dalam turnamen ini dan nilai tersebut memberikan kontribusi terhadap nilai kelompok awal; 5) siswa kembali ke meja kelompoknya (kelompok awal) dan melaporkan perolehan nilainya. Guru membandingkan akumulasi nilai kelompok dan memberikan penghargaan pada kelompok pemenang; 6) siswa mengikuti ujian. Pada metode tersebut peran aktif siswa sangat diperlukan dengan pengetahuan dibangun sendiri oleh siswa dan mereka bertanggung jawab atas hasil pembelajarannya. Siswa yang kurang mengerti dapat belajar dari siswa yang telah faham dalam kelompok-kelompok kecil. Pengetahuan siswa akan bertambah dengan permainan (turnament) pada saat proses pembelajaran. Hasil penemuan dari Arizona \& Harjono (2016) mengungkapkan bahwa siswa yang piawai dalam berkomunikasi baik dalam bahasa lisan maupun tulisan akan berdampak pada kemudahan siswa tersebut dalam menerima informasi berupa materi pelajaran dari guru maupun temannya. Jika siswa tersebut belum mengerti terhadap pelajaran, dia akan menanyakan hal tersebut kepada siswa yang lebih paham atau ke gurunya. Siswa yang cakap dalam bekerjasama akan memudahkan dia bekerja sebagai anggota dalam kelompok belajar atau sebagai siswa dalam kelas untuk memperoleh nilai yang baik pada saat diberikan tugas oleh guru. Seperti yang kita ketahui salah satu penilain hasil belajar kognitif diambil dari nilai tugas. Sehingga melalui kegiatan yang kolaboratif, aktivitas dan prestasi belajar siswa diharapkan meningkat.

\section{METODE}

\subsection{Jenis Penelitian}

Jenis penelitian yang digunakan dalam penelitian ini adalah penelitian tindakan kelas (PTK). Penelitian tindakan kelas merupakan suatu pencermatan terhadap kegiatan belajar berupa sebuah tindakan, yang sengaja dimunculkan dan terjadi dalam sebuah kelas secara bersama. Tindakan tersebut diberikan oleh guru atau dengan arahan dari 


\section{Mandalika Mathematics and Education Journal \\ Volume 2 Nomor 1, Juni 2020 e-ISSN 2715-1190 | | p-ISSN 2715-8292 \\ DOI: http://dx.doi.org/10.29303/mandalika.v2i1.1893}

guru yang dilakukan oleh siswa (Arikunto, dkk., 2014). Perbaikan dilakukan secara bertahap dan terus menerus selama kegiatan penelitian dilakukan. Oleh karena itu dalam PTK dikenal adanya siklus pelaksanaan berupa pola: perencanaan, pelaksanaan, observasi dan evaluasi, serta refleksi dan revisi (perencanaan ulang) pada siklus selanjutnya sampai mencapai target yang diinginkan (Natalia \& Dewi, 2009). Jadi, yang dimaksud dengan penelitian tindakan kelas dalam penelitian ini adalah kolaborasi antara guru (observer) dan peneliti (pengajar) dalam rangka mencapai tujuan pembelajaran, yakni meningkatkan aktivitas dan prestasi belajar siswa kelas X MIPA-3 SMAN 3 Selong melalui suatu tindakan tertentu dalam suatu siklus.

\subsection{Pendekatan Penelitian}

Pendekatan penelitian yang digunakan dalam penelitian ini adalah pendekatan kualitatif dan pendekatan kuantitatif. Pendekatan kualitatif adalah suatu proses penelitian dan pemahaman yang berdasarkan pada metodologi yang menyelidiki suatu fenomena sosial dan masalah manusia. Pendekatan Kuantitatif adalah suatu pendekatan yang berbentuk angka atau data kualitatif yang diangkakan/skoring. Pendekatan kuantitatif digunakan untuk mendapatkan data dari ketuntasan belajar siswa setelah proses belajar mengajar dengan menggunakan pembelajaran Kooperatif tipe Teams Games Tournaments.

\subsection{Waktu dan Tempat Penelitian}

Penelitian ini dilaksanakan dari tanggal 25 Maret 2020 sampai dengan 29 April 2020. Penelitian ini dilaksanakan di kelas X MIPA-3 SMA Negeri 3 Selong Tahun Pelajaran 2019/2020.

\subsection{Rancangan Penelitian}

Peneliti bekerja sama dengan guru lain dalam pelaksanaan pembelajaran diperoleh kesepakatan dan pemahaman yang sama terhadap masalah yang dihadapi. Peneliti menerapkan model pembelajaran kooperatif tipe TGT sedangkan guru sebagai observernya. Penelitan ini dilakukan untuk meningkatkan aktivitas dan prestasi belajar siswa dalam materi pokok trigonometri. Penelitian ini dilaksanakan dalam tiga siklus, setiap siklus terdiri dari empat tahapan yaitu perencanaan, pelaksanaan tindakan, observasi dan evaluasi,serta refleksi di akhir tindakan.

\subsection{Instrumen Penelitian}

Instrumen yang akan digunakan dalam penelitian ini berupa lembar observasi, perangkat mengajar (Lembar Kerjas Siswa/LKS, Skenario Pembelajaran/SP, Rencana Pelakasanaan Pembelajaran (RPP), dan Lembar Tes Evaluasi. Tes evaluasi berbentuk uraian. Metode tes digunakan untuk mengetahui sejauh mana kemampuan siswa dalam 


\section{Mandalika Mathematics and Education Journal \\ Volume 2 Nomor 1, Juni 2020 e-ISSN 2715-1190 | | p-ISSN 2715-8292 \\ DOI: http://dx.doi.org/10.29303/mandalika.v2i1.1893}

memahami materi pelajaran yang diberikan setiap akhir siklus pembelajaran. Instrumen ini disusun peneliti dengan disetujui oleh guru dan berpedoman pada kurikulum dan buku paket matematika yang digunakan.

\subsection{Teknik Pengumpulan dan Analisis Data}

Sumber data penelitian ini berasal dari guru matematika kelas $X$ yang lain dan siswa kelas X MIPA-3 SMAN 3 Selong Tahun Pelajaran 2019/2020. Jenis data yang didapatkan adalah kualitatif dan kuantitatif yang terdiri dari 1) data evaluasi hasil belajar siswa (data kuantitatif), 2) data aktivitas belajar siswa, dan 3) aktivitas guru (data kualitatif). Cara pengambilan data dalam penelitian ini yaitu 1) data hasil belajar diperoleh dengan cara memberikan tes evaluasi pada siswa setiap akhir siklus, dan 2) data tentang situasi dan aktivitas belajar mengajar diperoleh dari lembar observasi. Data yang telah didapatkan kemudian dianalisis secara kuantitatif. Data-data yang dianalisis pada penelitian ini adalah data aktivitas siswa, data aktivitas guru, data prestasi belajar, data ketuntasan individual dan klasikal.

\section{HASIL DAN PEMBAHASAN}

\subsection{Pelaksanaan Penelitian}

Penelitian Tindakan Kelas ini dilakukan untuk meningkatkan aktivitas dan prestasi belajar siswa pada materi pokok trigonometri Kelas X MIPA-3 SMAN 3 Selong dengan menggunakan model pembelajaran kooperatif tipe Teams Games Tournaments. Penelitian ini dilaksanakan dari tanggal 25 Maret 2020 sampai dengan tanggal 16 April 2020 yang terdiri dari 3 siklus. Dari hasil observasi dan tes evaluasi pada akhir siklus, diperoleh data kualitatif tentang aktivitas belajar siswa dan data kuantitatif tentang hasil belajar siswa.

\subsection{Data Hasil Penelitian}

\subsubsection{Data siklus I}

Dari hasil observasi yang dilakukan tercantum dalam lembar observasi aktivitas siswa diperoleh data aktivitas siswa yaitu pada pertemuan I diperoleh skor aktivitas siswa sebesar 20,75 dengan kriteria tinggi dan pada pertemuan II diperoleh skor aktivitas siswa sebesar 21,25 dengan berkriteria tinggi juga. Skor rata-rata aktivitas siswa yang diperoleh pada siklus I sebesar 21, ini berarti bahwa kriteria aktivitas belajar klasikal siswa dalam pembelajaran siklus I tergolong tinggi. Data lengkap mengenai aktivitas guru tersebut dapat dilihat bahwa jumlah skor yang diperoleh guru pada pertemuan I sebesar 21 dengan kriteria baik dan pada pertemuan II jumlah skor yang diperoleh sebesar 22 dengan kriteria baik juga. Dari pertemuan I dan pertemuan II diperoleh ratarata jumlah skor aktivitas guru sebesar 21,5 dengan kriteria baik. Data lengkap mengenai prestasi belajar siswa siklus I dapat dilihat, diperoleh data prestasi belajar siswa yaitu jumlah siswa mendapat nilai di bawah KKM sebanyak 12 siswa dari 35 siswa yang mengikuti evaluasi sehingga ketuntasan belajar siswa secara klasikal yang tercapai 
sebesar 65,71\%. Persentase ketuntasan ini belum mencapai ketuntasan klasikal sesuai dengan prosedur yang ada yaitu minimal $85 \%$ siswa mendapat nilai $\geq 67$, dengan demikian perlu dilakukan perbaikan pada siklus berikutnya. Dari hasil yang diperoleh pada siklus I dapat dilihat bahwa prestasi belajar siswa masih belum mencapai hasil yang diharapkan. Masalah-masalah yang terdapat pada siklus I akan diperbaiki pada siklus berikutnya.

\subsubsection{Data siklus II}

Data lengkap mengenai aktivitas belajar siswa selama proses pembelajaran pada siklus II dapat dilihat pada lampiran. Adapun hasil observasi aktivitas siswa dapat dilihat pada grafik berikut: data aktivitas siswa yaitu jumlah skor yang diperoleh pada siklus II pertemuan IV sebesar 22 dengan kriteria tinggi dan terjadi peningkatan dari siklus I yaitu dari 21 menjadi 22 walaupun sama-sama berkriteria tinggi. Pada siklus II observasi aktivitas guru juga dilakukan untuk melihat hasil refleksi yang telah dilakukan. kriteria penggolongan aktivitas guru pada bab III, dapat dilihat bahwa jumlah skor aktivitas guru pada siklus II yaitu sebesar 23 dengan kriteria sangat baik dan terjadi peningakatan dari siklus sebelumnya. Seperti pada siklus I, Setelah proses pembelajaran pada siklus II juga dilakukan evaluasi untuk mengetahui daya serap siswa yang diberikan dalam bentuk soal tes essay. Data lengkap tentang prestasi belajar siswa pada siklus II dapat dilihat, yaitu jumlah siswa mendapat nilai di bawah KKM sebanyak 8 siswa dari 34 siswa yang mengikuti evaluasi sehingga ketuntasan belajar siswa secara klasikal yang tercapai sebesar 76,47\%. Persentase ketuntasan ini belum mencapai ketuntasan klasikal sesuai dengan prosedur yang ada yaitu minimal $85 \%$ siswa mendapat nilai $\geq 75$, dengan demikian perlu dilakukan perbaikan pada siklus berikutnya. Dilihat dari hasil yang diperoleh pada siklus II juga belum mencapai hasil yang diharapkan. Masalah-masalah yang terdapat pada siklus II akan diperbaiki pada siklus berikutnya. Adapun rinciannya dapat dilihat pada tabel berikut:

Tabel 3 Rincian masalah pada siklus II dan perbaikannya

\begin{tabular}{|c|c|c|c|}
\hline No & Masalah & Perbaikan untuk guru & Perbaikan untuk siswa \\
\hline 1 & $\begin{array}{lr}\text { Komunikasi } & \text { dan } \\
\text { kerjasama siswa } & \text { pada } \\
\text { dasarnya sudah } & \text { baik } \\
\text { tetapi masih ada } & \text { siswa } \\
\text { yang masih } & \text { malu } \\
\text { bertanya pada temannya }\end{array}$ & $\begin{array}{l}\text { Guru memberikan motivasi } \\
\text { pada kelompok dan individu } \\
\text { yang sudah mengerti untuk } \\
\text { mengajak anggota } \\
\text { kelompoknyayang diam dan } \\
\text { tidak ikut bekerja sehingga } \\
\text { diskusi berjalan dengan lebih } \\
\text { baik }\end{array}$ & $\begin{array}{l}\text { Siswa yang sudah } \\
\text { mengerti agar mengajak } \\
\text { temannya yang belum } \\
\text { mengerti untuk berdiskusi } \\
\text { bersama sehingga semua } \\
\text { anggota kelompok bisa } \\
\text { menanyakan apa yang } \\
\text { belum dimengerti. }\end{array}$ \\
\hline 2 & $\begin{array}{lr}\text { Pada saat } & \text { diskusi } \\
\text { kelompok, } & \text { beberapa } \\
\text { siswa masih } & \text { mengalami } \\
\text { kesulitan } & \text { dan } \\
\text { memerlukan waktu yang }\end{array}$ & $\begin{array}{l}\text { Guru menambahkan waktu } \\
\text { untuk diskusi kelompok } \\
\text { menjadi } 30 \text { menit. Dan guru } \\
\text { juga menjelaskan tentang } \\
\text { pentingnya pembagian tugas } \\
\text { dalam kelompok agar semua }\end{array}$ & 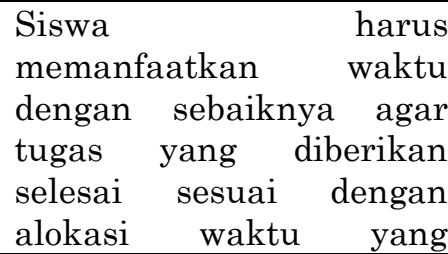 \\
\hline
\end{tabular}




\begin{tabular}{|c|c|c|}
\hline & Manc & $\begin{array}{r}\text { alika Mathematics and Education Journal } \\
\text { Volume } 2 \text { Nomor 1, Juni } 2020 \\
\text { e-ISSN 2715-1190| | p-ISSN 2715-8292 } \\
\text { DOI: http://dx.doi.org/10.29303/mandalika.v2i1.1893 }\end{array}$ \\
\hline & $\begin{array}{l}\text { cukup banyak untuk } \\
\text { menemukan jawaban }\end{array}$ & 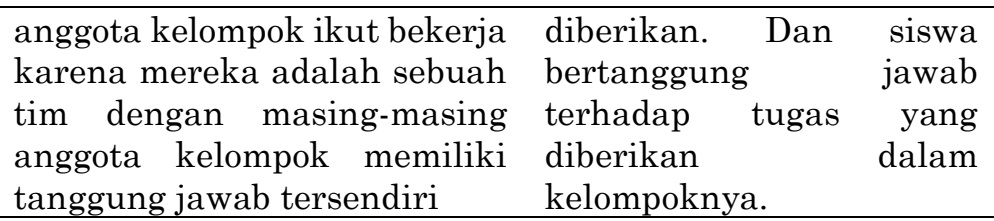 \\
\hline 3 & $\begin{array}{lr}\text { Pada saat permainan } \\
\text { kartu soal berlangsung, } \\
\text { masih ada beberapa } \\
\text { kelompok yang } & \text { masih } \\
\text { mengandalkan ketua } \\
\text { kelompok } \quad \text { untuk } \\
\text { menyelesaikan } \\
\text { permainan }\end{array}$ & $\begin{array}{lrrr}\text { Guru menekankan bahwa } & \text { Anggota } & \text { kelompok } \\
\text { setiap kelompok yang } & \text { sebaiknya mencoba } \\
\text { mendapat giliranagar anggota } & \text { memaparkan hasil yang } \\
\text { kelompoknyadapatmembantu } & \text { sudah dijawab dalam } \\
\text { ketua kelompoknya dan } & \text { kelompoknya sehingga } \\
\text { bersedia maju untuk } & \text { bukan hanya ketua } \\
\text { memaparkan hasilnya. } & & \text { kelompok saja yang maju. }\end{array}$ \\
\hline
\end{tabular}

\subsubsection{Data siklus III}

Pada siklus III juga dilakukan observasi aktivitas siswa untuk mengetahui hasil dari refleksi yang telah dilakukan. Data lengkap mengenai aktivitas belajar siswa selama proses pembelajaran pada siklus III dapat dilihat yaitu jumlah skor yang diperoleh pada siklus III pertemuan VI sebesar 23dengan kriteria sangat tinggidan terjadi peningkatan dari siklus II. Pada siklus III juga dilakukan observasi tentang aktivitas guru seperti yang telah dilakukan pada siklus sebelumnya. Kriteria penggolongan aktivitas guru pada bab III, dapat dilihat bahwa jumlah skor aktivitas guru pada siklus III yaitu sebesar 24 dengan kriteria sangat baik dan terjadi peningakatan dari siklus sebelumnya. Seperti pada sebelumnya, setelah proses pembelajaranpada siklus III juga dilakukan evaluasi untuk mengetahui daya serap siswa setelah melakukan refleksi yang diberikan dalam bentuk soal tes essay. Data prestasi belajar siswa yaitu jumlah siswa mendapat nilai di bawah KKM sebanyak 3 siswa dari 33 siswa yang mengikuti evaluasi sehingga ketuntasan belajar siswa secara klasikal yang tercapai sebesar 90,09\%. Persentase ketuntasan ini sudah mencapai ketuntasan klasikal yang telah ditetapkan yaitu minimal $85 \%$ siswa mendapat nilai $\geq 75$, dengan demikian kegiatan pembelajaran sampai siklus.

Berdasarkan hasil yang diperoleh dan tindakan yang dilakukan pada siklus III, ternyata target yang ditetapkan oleh kurikulum sudah tercapai. Dengan demikian, maka pada siklus berikutnya dapat dihentikan karena telah diperoleh informasi-informasi yang cukup untuk mengambil beberapa keputusan sehubungan dengan tujuan penelitian ini.

\subsection{Analisis Data}

Dari data-data yang telah diperoleh, selanjutnya dianalisa untuk mengetahui hubungan setiap siklusnya. Untuk aktivitas siswa, pada siklus I diperoleh jumlah skor sebesar 21 sehingga berkriteria tinggi. Walaupun sudah berkriteria tinggi tetapi masih ada beberapa siswa yang belum melaksanakan deskriptor. Pada siklus II juga kriteria yang diperoleh masih tinggi dengan jumlah skor 22, tetapi terjadi peningkatan jumlah skor 


\section{Mandalika Mathematics and Education Journal \\ Volume 2 Nomor 1, Juni 2020 e-ISSN 2715-1190 | | p-ISSN 2715-8292 \\ DOI: http://dx.doi.org/10.29303/mandalika.v2i1.1893}

yang diperoleh. Pada siklus III jumlah skor yang diperoleh untuk aktivitas siswa sebesar 23 dengan kriteria sangat tinggi dan tejadi peningkatan dari sebelumnya berkriteria tinggi menjadi sangat tinggi. Selain aktivitas siswa yang meningkat, aktivitas guru juga meningkat. Hal ini dapat dilihat pada setiap siklusnya yaitu pada siklus I rata-rata skor yang diperoleh sebesar 21,5 sehingga berkriteria baik. Pada siklus II kriteria aktivitas guru sudah meningkat menjadi sangat aktif dengan skor 23. Sedangkan pada siklus III diperoleh jumlah skor sebesar 24 sehingga berkriteria sangat aktif juga, tetapi telah terjadi peningkatan dari jumlah skornya.

Dan untuk prestasi belajar siswa juga terjadi peningkatan dari tidak tuntas secara klasikal menjadi tuntas secara klasikal. Pada siklus I jumlah siswa yang mendapat nilai dibawah KKM sebanyak 12 siswa dari 35 siswa yang mengikuti evaluasi sehingga ketuntasan klasikal yang diperoleh sebesar 65,71\%. Sedangkan pada siklus II jumlah siswa yang nilainya dibawah KKM sebanyak 8 siswa dari 34 siswa yang mengikuti evaluasi sehingga ketuntasan klasikal yang diperoleh sebesar 76,47\%. Walaupun ada kenaikan dari ketuntasan klasikalnya tetapi belum mencapai indikator kerja yang telah ditetapkan yaitu ketuntasan klasikal yang diperoleh minimal 85\%. Dan pada siklus III jumlah siswa yang nilainya dibawah KKM sebanyak 3 siswa dari 33 siswa yang mengikuti evaluasi sehingga ketuntasan klasikalnya sebesar 90,09\%. Oleh karena itu, sudah terjadi Berdasarkan analisis data di atas dapat disimpulkan bahwa: 1)Tejadi peningkatan aktivitas belajar siswa dari siklus I sampai dengan siklus III secara berturut-turut dengan kriteria tinggi, tinggi, dan sangat tinggi, 2) Terjadi peningkatan ketuntasan belajar siswa secara klasikal dari siklus I sampai dengan siklus III yaitu pada siklus I sebesar 67,41\% (tidak tuntas), Siklus II sebesar 76,47\% (tidak tuntas), dan siklus III sebesar 90,09\% (tuntas). Oleh karena itu, maka diperoleh jawaban dari hipotesis bahwa penerapan model kooperatif tipe Teams Games Tournaments (TGT) pada pembelajaran materi pokok trigonometri dapat meningkatkan aktivitas dan prestasi belajar siswa kelas X MIPA-3 SMAN 3 Selong tahun pelajaran 2019 / 2020.

\subsection{Pembahasan}

Berdasarkan analisis data, pelaksanaan tindakan pada siklus I menunjukkan bahwa persentase ketuntasan yang diperoleh sebesar 65,71\%. Ini berarti bahwa prestasi belajar siswa belum tuntas. Hasil observasi aktivitas siswa pada siklus I menunjukkan bahwa kriterianya sudah tinggi tetapi masih ada beberapa deskriptor yang kriterianya cukup tinggi. Ini berarti bahwa masih banyak siswa yang belum melaksanakan deskriptor yang diteliti. Begitu juga dengan aktivitas guru, walaupun berkriteria baik tetapi masih ada beberapa deskriptor yang belum terlaksana. Hal ini disebabkan oleh: 1) Guru masih kurang dalam pengawasan dan mengarahkan siswa dalam melakukan diskusi kelompok., 2) Komunikasi dan kerjasama siswa dalam kelompok nampak kurang. Siswa yang berkemampuan tinggi masih enggan bekerjasama dengan temannya yang 
berkemampuan rendah demikian juga halnya dengan siswa yang berkemampuan rendah ada yang masih enggan bertanya pada temannya yang berkemampuan tinggi, 3) Pada saat siswa diberikan kesempatan untuk diskusi kelompok, beberapa siswa mengalami kesulitan dan memerlukan waktu cukup banyak untuk menemukan jawaban, 4) Pada saat permainan kartu soal berlangsung, kelompok yang mendapat giliran masih mengandalkan ketua kelompoknya saja, dan 5) Masih ada siswa yang malu bertanya dan menjawab. Untuk mengatasi masalah tersebut guru melakukan perbaikan-perbaikan dalam pembelajaran dan mengoptimalkan hal-hal yang masih dianggap kurang. Perbaikan-perbaikan yang dilakukan pada pertemuan selanjutnya adalah sebagai berikut:

1) Guru harus lebih aktif memberikan bimbingan pada tiap-tiap kelompok dengan terus mengawasi dan mengarahkan siswaagar dapat memahami isi dari LKS yang telah dibagikan.

2) Guru memberikan motivasi pada kelompok dan individu yang sudah mengerti agar mau mengajari temannya yang belum mengerti.

3) Guru menambahkan waktu untuk diskusi kelompok yang awalnya 20 menit menjadi 25 menit. Dan guru juga harus menjelaskan tentang pentingnya pembagian tugas dalam kelompok agar semua anggota kelompok memiliki tanggung jawab.

4) Guru menekankan bahwa setiap kelompok yang mendapat giliran semua anggotanya harus membantu ketua kelompoknya dan bersedia maju untuk memaparkan hasilnya.

5) Guru memotivasi siswa dengan cara memberikan pertanyaan sebagai apersepsi agar siswa menjadi terbiasa dalam menjawab pertanyaan. Berdasarkan hasil analisa data pada siklus II,ketuntasan klasikal yang diperoleh sebesar 76,47\%. Persentase ketuntasan ini juga belum mencapai ketuntasan klasikal sesuai dengan prosedur yang ada yaitu minimal $85 \%$ siswa mendapat nilai $\geq 75$, dengan demikian perlu dilakukan perbaikan pada siklus berikutnya.

Hasil observasi aktivitas guru pada siklus II menunjukkan bahwa kriterianya sudah sangat baik, sedangkan untuk aktivitas siswa menunjukkan bahwa kriterianya tinggi. Walaupun secara klasikal berkriteria tinggi tetapi masih ada beberapa siswa yang kurang aktif dalam kelompoknya. Adapun penyebabnya antara lain :

1) Komunikasi dan kerjasama siswa pada dasarnya sudah baik tetapi masih ada siswa yang masih malu bertanya pada temannya.

2) Pada saat diskusi kelompok, beberapa siswa masih mengalami kesulitan dan memerlukan waktu yang cukup banyak untuk menemukan jawaban.

3) Pada saat permainan kartu soal berlangsung, masih ada beberapa kelompok yang masih mengandalkan ketua kelompok untuk menyelesaikan permainan.

Mengatasi masalah tersebut guru melakukan perbaikan-perbaikan dalam pembelajaran dan mengoptimalkan hal-hal yang masih dianggap kurang. Oleh karena itu, perbaikanperbaikan yang dilakukan adalah sebagai berikut

1) Guru memberikan motivasi pada kelompok dan individu yang sudah mengerti untuk mengajak anggota kelompoknyayang diam dan tidak ikut bekerja sehingga diskusi berjalan dengan lebih baik. 


\section{Mandalika Mathematics and Education Journal \\ Volume 2 Nomor 1, Juni 2020 e-ISSN 2715-1190 | | p-ISSN 2715-8292 \\ DOI: http://dx.doi.org/10.29303/mandalika.v2i1.1893}

2) Guru menambahkan waktu untuk diskusi kelompok menjadi 30 menit. Dan guru juga menjelaskan tentang pentingnya pembagian tugas dalam kelompok agar semua anggota kelompok ikut bekerja karena mereka adalah sebuah tim dengan masingmasing anggota kelompok memiliki tanggung jawab tersendiri.

3) Guru menekankan bahwa setiap kelompok yang mendapat giliranagar anggota kelompoknyadapatmembantu ketua kelompoknya dan bersedia maju untuk memaparkan hasilnya.

Berdasarkan hasil analisa data pada siklus III, ketuntasan klasikal yang diperoleh sebesar 90,09\%. Persentase ketuntasan ini sudah mencapai ketuntasan klasikal yang telah ditetapkan yaitu minimal $85 \%$ siswa mendapat nilai $\geq 67$. Jumlah skor aktivitas siswa yang diperoleh pada siklus III sebesar 22,75 sehingga berkriteria sangat tinggi, sedangkan jumlah skor aktivitas guru sebesar24sehingga berkriteria sangat baik. Oleh karena itu, penelitian ini hanya sampai siklus III karena prestasi belajar, aktivitas siswa serta aktivitas guru telah mencapai yang ditargetkan.

Seperti apa yang telah diuraikan di atas, maka pembelajaran kooperatif tipe TGT dapat meningkatkan prestasi belajar siswa. Hal ini dapat dilihat dari hasil dan aktivitas belajar yang diperoleh pada tiap-tiap siklus.

1) Siswa bertanggung jawab atas segala sesuatu didalam kelompoknya,

2) Siswa dapat melihat bahwa semua anggota didalam kelompoknya memiliki tujuan yang sama,

3) Siswa bisa membagi tugas dan tanggung jawab yang sama diantara anggota kelompoknya,

4) Siswa akan dikenakan evaluasi atau diberikan penghargaan yang juga akan dikenakan untuk semua anggota kelompok,

5) Siswa berbagi kepemimpinan dan mereka membutuhkan keterampilan untuk belajar bersama selama proses belajarnya, dan

6) Siswa akan diminta mempertanggung jawabkan secara individual materi yang ditangani dalam kelompok kooperatif.

Temuan dari hasil penelitian sesuai dengan penelitian Apriza (2017) yang menyatakan pembelajaran model kooperatif tipe TGT dengan media permainan konsentrasi berpengaruh terhadap aktivitas dan hasil belajar IPS siswa kelas V. Begitu juga dengan hasil penelitian Utari, dkk. (2018) terdapat pengaruh model pembelajaran kooperatif tipe teams games tournament terhadap hasil belajar siswa pada mata pelajaran ekonomi di SMA Muhammadiyah 2 Palembang. Sejalan dengan hasil penelitian Oktarina, dkk. (2019) yang mengungkapkan ada pengaruh model pembelajaran Teams Games Tournament terhadap hasil belajar peserta didik pada mata pelajaran ekonomi di SMA Sandika Sukajadi.

\section{PENUTUP}

Dari hasil penelitian dan pembahasan, dapat disimpulkan bahwa penerapan model kooperatif tipe Teams Games Tournaments (TGT) pada pembelajaran materi pokok trigonometri dapat meningkatkan aktivitas belajar siswa kelas X MIPA-3 SMAN 3 
Selong tahun pelajaran 2019/2020. Peningkatan ini dapat dilihat dari perolehan skor rata-rata aktivitas belajar siswa pada siklus I sebesar 21 dengan kriteria tinggi, siklus II sebesar 22 dengan kriteria tinggi juga. Sedangkan pada siklus III skor yang diperoleh sebesar 22,25 dengan kriteia sangat tinggi. Peningkatan aktivitas juga terjadi pada kegiatan guru yaitu pada siklus I skor yang diperoleh sebesar 21,5 dengan kriteria baik, siklus II sebesar 23 dengan kriteria sangat baik, dan pada siklus III skor yang diperoleh sebesar 24 dengan kriteria sangat baik. Penerapan model kooperatif tipe Teams Games Tournaments (TGT) pada pembelajaran materi pokok trigonometri dapat meningkatkan prestasi belajar siswa kelas X MIPA-3 SMAN 3 Selong tahun pelajaran 2019/2020. Peningkatan ini dapat dilihat dari ketuntasan klasikal yang diperoleh sebesar 65,71\%pada siklus I. Sedangkan pada siklus II, ketuntasan klasikal yang diperoleh sebesar 76,47\%. Dan pada siklus III ketuntasan klasikal yang diperoleh sebesar 90,09\%.

\section{UCAPAN TERIMA KASIH}

Ucapan terima kasih kami sampaikan kepada: 1) Bapak kepala sekolah SMA Negeri 3 Selong yang telah memberikan waktu untuk dapat melaksanakan penelitian tindakan kelas ini, 2) Bapak ibu guru yang telah banyak mendukung dan memberikan saran atas pelaksanaan penelitian ini sehingga terlaksana dengan baik dan lancar.

\section{REFERENSI}

Apriza. (2017). Pengaruh Penggunaan Model Pembelajaran Kooperatif Tipe Teams Games Tournament (Tgt) Dengan Media Permainan Konsentrasi Terhadap Aktivitas Dan Hasil Belajar Ips Kelas V. Jurnal Review Pendidikan Dasar: Jurnal Kajian Pendidikan dan Hasil Penelitian, 3 (3), 463-473.

https://journal.unesa.ac.id/index.php/PD/article/view/3807

DOI: $\underline{10.26740 / \text { jrpd.v3n3.p463-473 }}$

Arizona, K., Harjono, A. \& Jufri, A.W. (2013). Pengaruh Implementasi Media Tiga Dimensi Kemagnetan Berbasis Inkuiri (MTDKBI) melalui Strategi Kooperatif terhadap Kecakapan Sosial. Jurnal Erudio, 1(2), 134-138. https://erudio.ub.ac.id/index.php/erudio/article/view/129

Arizona, K., \& Harjono, A. (2016). Korelasi Kecakapan Sosial, Sikap Ilmiah, dan Hasil Belajar Kognitif Fisika Siswa SMP. Konstan, 2(1), 5-8.

https://scholar.google.com/scholar?hl=en\&as_sdt=0,5\&cluster $=12603546181675171478$

Harjono, A., Jufri, A.W., \& Arizona, K. (2015). Implementasi Media Tiga Dimensi Kemagnetan Berbasis Inkuiri Melalui Strategi Kooperatif Terhadap Sikap Ilmiah Siswa. Jurnal Pendidikan Fisika dan Teknologi, 1(1), 15-23. http://jurnalfkip.unram.ac.id/index.php/JPFT/article/view/231

DOI: http://dx.doi.org/10.29303/jpft.v1i1.231

Oktarina, H., Barlian, I., \& Jaenudin, R. (2019). Pengaruh Penerapan Model Pembelajaran Teams Games Tournament terhadap Hasil Belajar Peserta Didik pada Mata Pelajaran Ekonomi Kelas X di SMA Sandika Sukajadi (Doctoral dissertation, Sriwijaya University). http://repository.unsri.ac.id/937/

Huda, Miftahul. (2013). Model-model Pengajaran dan Pembelajaran. Yogyakarta: Pustaka Pelajar.

Natalia, M.M., \& Dewi, K.I. (2009). Penelitian Tindakan Kelas. Bogor: Regina. 
Sani, R.A. (2014). Inovasi Pembelajaran. Jakarta: Bumi Aksara

Suharsimi, A., Suhardjono \& Supardi. (2014). Penelitian Tindakan Kelas. Jakarta: Bumi Aksara. Utari, F. D., \& Barlian, I. (2018). Pengaruh Model Pembelajaran Kooperatif Tipe Teams Games Tournament terhadap Hasil Belajar Siswa pada Mata Pelajaran Ekonomi di SMA Muhammadiyah 2 Palembang. Jurnal PROFIT Kajian Pendidikan Ekonomi dan Ilmu Ekonomi, 5(1), 40-49.

https://ejournal.unsri.ac.id/index.php/jp/article/view/5635/0

DOI: https://doi.org/10.36706/jp.v5i1.5635 